\title{
Impact of Organizational Justice and Organizational Citizenship Behavior on Employees Performance
}

\author{
Samreen Ismail \\ Student at Department of Business Administration \\ University of Kotli Azad Kashmir, Pakistan \\ Zafar Iqbal \\ Lecturer at Department of Business Administration \\ University of Kotli Azad Kashmir, Pakistan \\ Muhammad Adeel (Corresponding author) \\ Lecturer at Department of Business and Management Sciences \\ Mirpur University of Science and technology (MUST) \\ E-mail: adeelbashir06@gmail.com
}

Received: Jan. 15, 2018 Accepted: Feb. 12, 2018 Online published: Apr. 28, 2018

doi:10.5296/ijhrs.v8i2.13070 URL: https://doi.org/10.5296/ijhrs.v8i2.13070

\begin{abstract}
Organizational Justice has been considered a significant subject in the operative organizations functioning. Whereas Organizational Citizenship Behavior is important to achieve the organizational success therefore organizations encourage and facilitate the OCB in order to produce effectiveness and efficiency in organization functions. The primary aim of this research is to investigate the role of organizational justice and organizational citizenship behavior in enhancing employees' performance in academic setting. Organizational justice plays a pivotal role in shaping individual behavior and particularly extra role behavior such organizational citizenship behavior. To answer the research question, the cross sectional data were collected through a questionnaire from 190 employees working in different universities of Azad Kashmir Pakistan. Our findings reveal that there is a significant positive association among organizational justice (OJ), organizational citizenship behavior (OCB) and Employees performance (EP). The results indicated that Organizational Justice and Organization
\end{abstract}


Citizenship Behaviors was significant predictor of Employees performance. This research contributes to the managerial literature by identifying and applying theoretical concepts into a different sample and organizational settings.

Keywords: organizational justice, organizational citizenship behavior, employees' performance

\section{Introduction}

In today's modest setting, the organization effectiveness is considered the most important factor for organization's profitability and sustainability. Therefore, each individual should be responsible within the organization to achieve the organizational effectiveness. Thus, it can be said that OCB is to be considered important factor for achieving organization success (Farh, 1997). Bateman and Organ (1983) were the first who defined the term OCB as "the behavior of the worker which was not described but arisen freely to help others in attaining the different mission and task." Organ (1988) suggested that OCB plays important role in helping the organization to survive.

Today's employees are working with a climate which motivates them towards self-development by encouraging not only in job responsibility but also develop Organizational Citizenship Behaviors. Adams (1965) argued that pervious researches reveal that Organization Justice has ability to explain the Organizational outcomes variables. Organization Justice concerned with the employees perception previous studies have shown that determination of fair judgment is translated into key behavior on the job. While making relations between perceptions of justice and consequent behaviors, further research is required to find out what type of behavior take place and how these behaviors are fruitful for the organization. For this purpose, fairness and subsequent behavior i.e. OCB were examined in relation to the employee's performance. This research work was demonstrated how judgment of workplace fairness and Citizenship Behavior may affect the employees performance. To give the reader deep understanding, this research work define and describe the key ideas and concepts, background of the research area, research objectives, research questions and its significance of the study regarding the Organization Justice and Organization Citizenship Behavior. For this purpose, it is important to explain each concept separately, and then link them properly through common principles and ideas.

Indeed, most of the recent studies on $\mathrm{OCB}-\mathrm{OJ}$ (organizational justice) relation have been conducted in Pakistan but such studies have not been conducted to check the impact of both OCB and OJ on employees' performance at the same time in academic context in Pakistan as well as this study will be conducted first time in AJK. Therefore, this research attempts to fill the gap to study the effect of Organizational Justice and Citizenship Behaviors on Employees Performance in AJ\&K Universities. The result of this study may help the decision makers or leaders in academic sector to better understand the relationship between OCB and OJ and its impact on employee performance which in turn improve their performance and enhance the productivity. It will not only increase overall efficiency of the organizations but also affects the employees' perception concerning the workplace and behavior in positive way. 


\section{Literature Review}

\subsection{Organizational Citizenship Behavior}

Organizational Citizenship Behavior has been defined by Organ (1988) as "employee controlled behavior that could or could not reward by the organization but it add to organization by improving the whole quality of setting where work take place". Organizational Citizenship Behavior is an important construct to consider because it contributes to the increment of the individual's motivation towards the organization.

Cohen and Vigoda (2000) suggested that when there is uniformity and fairness in rules and procedures applied by the organization then it will cause a noticeable display in extra-role behaviors of employees. OCB is important to achieve the organizational success therefore organizations encourage and facilitate the OCB in order to produce effectiveness and efficiency in organization functions (Eisenberger, Huntington, Hutchison, \& Sowa, 1986). Folgers (1986) suggested that over duties behavior of staff is caused by polite and courteous behavior of supervisor with their subordinates as well as by providing timely information to employees. Organ recognized OCB as a conscious and autonomous behavior which increases organizational productivity. The vital role of Organizational Citizenship Behavior for organizational success has long been acknowledged by committed managers. OCB can be characterized as the collaborative behavior which stimulate the positive attitude of employee to the organization and enhance the effort level of individual that is helpful for the firm (Abili, 2009). According to Senobari (2008) OCB is considered by surplus workload that is made by individuals. OCB basically want to make contribution in the production, customer satisfaction, employee satisfaction, and quality by defining the employees' willingness to give up their exertion and collaborate with the organization. Organizational Citizenship Behavior has a vital role for organizational effectiveness (Erturk, 2007). According to Cohen and Vigoda (2000) OCB shows employees' availability and eagerness to practice which cause successful application of new procedures of management.

\subsubsection{Organizational Justice}

Organization Justice has been considered a significant subject in the operative organizations functioning (Lind \& Tyler, 1988). Widespread studies have focused to investigate the effect of Organizational Justice on employees' performance. It can be defined as Employees perception of fairness behavior acknowledged from their organizations (Cropanzano \& Greenberg, 1997). According to Organ (1988) "Organization Justice state that "the degree to which employee are fairly treated in organization". Greenberg and Tyler proposed that people are worried about justice and that Justice influences the job attitudes as well as wide variety of organizational behaviors. Abili (2009) proposed that justice need fair rules and procedures that accommodate the access of every person from law. Fair treatment can be viewed as a personal assessment about organizational behavior and ethical standing (Cropanzano, 2007).

Justice at a workplace can lead to employees' high commitment and over duties jobs (Yaghobi, 2010). From the empirical evidence it has been found that multiplicity of progressive work behavior and attitude is significantly related with organizational justice 
Zeinabadi and Salehi (2011). Hence, fairness plays a significant role in organization practices to construct a competitive advantage. In today's competitive environment, organizations are continuously trying to maintain the best aptitude and gain competitive advantage from their rivals by exploit the similar things contrarily. Zinta (2005) proposed that employees give importance to the employer's sense of fairness when they become more conscious of their trustworthiness by supposing that they will treat them fairly. Thus, justice has become a main aspect for organizations who take a profound consideration because it openly upsets workplace attitudes and behavior. Gadot (2007) argued that in order to expand the trust constructing ability of their workers, organization should communicate the human resources activities that encourage fair dealing of employees. According to Messer and White (2006) when employees ponder that they are being fairly treated by their managers and superiors and their firm is worried about each and every individual employee's welfare, they would make a sensible working effort to return not only for their superiors but also for their organization in suitable way.

\subsubsection{Employees Performance}

Zeinabadi and Salehi, (2011) defined employees as "any individual truly hired b an organization or whose work directly influence and relates to the basic economic functions of the firm". Guangling (2011) argued that employees are insider part of the working principal and often seek recognition with their organization. Lichtenstein (2008) defined employee's performance as "The job related activities Employees dedicate their knowledge, skills, experiences and creativity to the organization, which makes them critical to the success of the organization". It is even stated that people play a large part in making or breaking the organization. Place (2010) argued that the power of an organization lies in the hands of good people. Some employees are able to work independently with little or no supervision, while others require considerable guidance to perform a job well. The differences between employees can be measured by identifying and comparing their competencies and behavioral characteristics (Leventhal, 1976). Employees' perception of the organizations commitment intensely influenced the psychological attachment of individuals to an organization. Adeel, Hashmi, and Iqbal (2017) suggested that organization needs to enhance the job performance of its employees for the betterment of the organization by motivating and creating a sense of commitment.

Cohen and Vigoda (2000) argued that when the incentives exceed employee expectations and involvement then they tend to develop strong commitment and when the incentives do not exceed expectations, commitment does not occur. For example, Podsakoff, MacKenzie, paine, and Bachrach (2000) suggested that OCB and OJ effect the constancy of employees' performance because "meticulous employees are more likely to retain a regularly great level of output, thus decreasing inconsistency in a work division performance" (p. 545). Hence, employees often depend on their work for social relationship, self-actualization, and self-identity because they have great influenced on the success and failure of the organization (Konovsky \& Pugh, 1994). Besides, employees are critical to an organization's success and failure. 


\section{Macrothink}

International Journal of Human Resource Studies

ISSN 2162-3058 2018, Vol. 8, No. 2

2.2 Relationship between Organizational Justice and Organizational Citizenship Behavior

Researchers have continuously shown that individuals' behavior at place of work is influenced by perception of Organization Justice (Colquitt et al., 2001). Blakely (2005) proposed that when employees have positive perceptions about the fair behavior of supervisor then the possibility of OCB increases. According to Cohen and Vigoda (2000) Organizational Justice explains why the employees react against injustice results or inappropriate processes and inter-connections. Guangling (2011) found that when low levels workers have higher level of perception of Organization justice then they show greater ability to involve and partake in OCB. Furthermore, it has been found that low level employees avoid rebellious behaviors. Neami and Shokrkon (2004) stated that justice at the place of work might be specifically important to the occurrence of OCB because justice brings positive change in the minds of employees regarding their relationship with organization.

\subsection{Theoretical Framework}

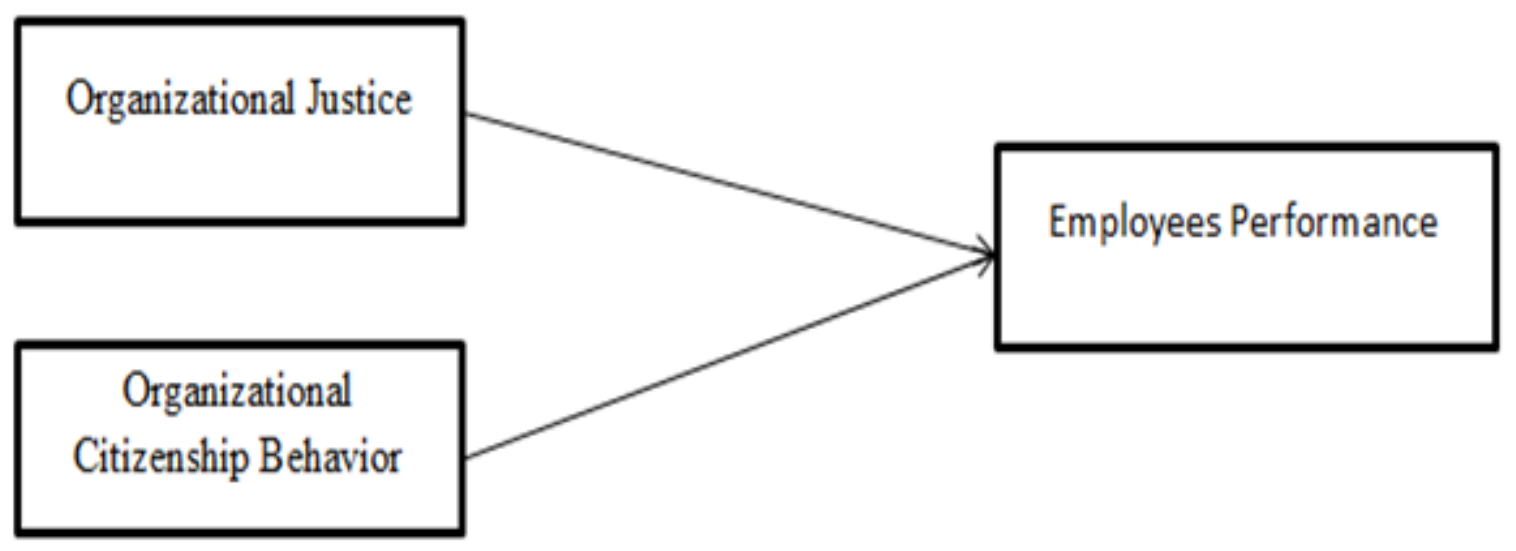

\subsection{Proposed Hypothesis}

According to the previous assessment, the current study aim is to test the following hypothesis.

$\mathrm{H}_{1}$.Organization Justice has significant impact on employees' performance.

$\mathrm{H}_{2}$. Organizational Citizenship Behavior has a significant impact on employees' performance.

$\mathrm{H}_{3}$. Organizational Justice is positively correlated with Organization Citizenship Behavior.

\section{Methodology}

\subsection{Research Design}

Research design is primarily an approach, whereby the theory, can be at least tested indirectly. The aim of current study was to check the impact of Organizational Justice and Organizational Citizenship Behavior on Employees Performance. The Explanatory type of research were used for present study in order to investigate which variables might be causing definite behavior i.e. is there is a cause and effect relationship between variables, then this research must be started. Some statistical tools and techniques were used on data such as 
Regression Analysis and Pearson Correlation with the help of SPSS (Statistical Package for Social Sciences).

Data were collected from both primary and secondary source. Primary data were collected through directing questionnaires among selected sample of teachers teaching in Azad Jammu and Kashmir Universities and secondary data were collected from different articles, theories and research paper.

\subsection{Population and Sample Population}

The target population was full-time faculty members teaching in Universities of Azad Jammu Kashmir. The population of present study was almost 700 employees of Universities in state of Azad Jammu and Kashmir (Must, Poonch, Umsit and Ajk).

The sample of current study mainly consisted of employees of 4 Universities in Azad Jammu and Kashmir. For this purpose, full- time faculty members of 4 Universities were approached through the personal contacts. The total numbers of employee contacted and requested to complete the questionnaires were 250. Out of these, 190 completed questionnaires were collected on a mutually agreed time that yields the response rate $78 \%$. The distribution composition of questioner among each university faculty member is presented below in table 3.1 .

Table 3.1. List of Universities and Number of Respondents

SNo. HEC Recognized Universities 2015 in Azad Janmu and No of Respondents

Kashmir

1 University of Azad Jammu and Kashmir

60

1 University of Management Sciences and Information Technology

65 Kotli

3 Mirpur University of Sciences and Technology

60

4 Poonch University Rawalakot

65

\subsection{Reliability Analysis}

In current study Cronbach Coefficient Alpha was used to determine the reliability of variables. Basically, it is internal reliability of items scale which tells us whether items have link with each other or not and measured in single construct. Cronbach Coefficient Alpha value ranges 


\section{Macrothink}

International Journal of Human Resource Studies

ISSN 2162-3058 2018, Vol. 8, No. 2

from 0 to 1 . Alpha values " 0.7 " are considered to be more consistent whereas values below 0.7 are considered to be less consistent (Moorman, 1991).

Table 3.2. Reliability Analysis (Chronbach Alpha)

\begin{tabular}{lcc}
\hline Variables & No of item & Chronbach Alpha \\
\hline Organization Justice (OJ) & 11 & 0.76 \\
Organization Citizenship Behavior(OCB) & 9 & 0.73 \\
Employees Performance(EP) & 7 & 0.71 \\
\hline
\end{tabular}

Table; 3.2 has shown the reliability analysis of all the scale used in present study. Table 6 shows that all scale used in present study were found to be quite reliable with alpha value for organizational justice was ' 0.76 ' alpha value for organizational citizenship behavior was ' 0.73 ' and alpha value for employee performance was ' 0.71 '.

\section{Data Analysis and Results}

\subsection{Correlation Analysis}

Correlation analysis refers to the degree of the relationship between binary variables. The correlation values usually lies between $(-1$ to +1$)$, whereas the positive or negative sign represent the relationship direction. Positive sign represent positive relation among variables while negative sign represent inverse relation among variables whereas 0 show that there is no relationship among variables. Below table represents the correlation among study variables i.e. Gender, Age, Designation, Organizational Justice, Organizational Citizenship Behavior and Employee Performance.

\begin{tabular}{lccc}
\hline & OJ & OCB & EP \\
\hline Organizational Justice & 1 & & \\
Organizational Citizenship Behavior & $.247^{* *}$ & 1 & \\
Employee Performance & & & \\
\hline
\end{tabular}

*. Correlation is significant at the 0.05 level (2-tailed).

**. Correlation is significant at the 0.01 level (2-tailed)

A Pearson product-moment correlation analysis was used to investigate the relationship 


\section{Macrothink}

International Journal of Human Resource Studies

ISSN 2162-3058 2018, Vol. 8, No. 2

among variables Organizational Justice, Organizational Citizenship Behavior and Employees Performance. The investigated variables Organization Justice, Organization Citizenship Behavior and Employees Performance were intake. The hypothesis states that there is a significant relationship among these variables. Findings shown that Employees Performance was significantly correlated with Organization Justice $(r=.276, \mathrm{P}<0.05)$ and Citizenship Behavior ( $\mathrm{r}=.309, \mathrm{P}<0.005)$, Organization Justice and Organization Citizenship Behavior was also significantly correlated with each other $(r=.247, \mathrm{P}<0.05)$.

\subsection{Control Variables}

One way ANOVA is carried out to fine whether these demographic variables are significantly related to employees performance or not in current study. Result of one way ANOVA for demographic variables is presented below.

\begin{tabular}{lll}
\hline Variables & $F$ & Sig. \\
\hline Gender & 1.276 & .281 \\
Age & 507 & .678 \\
Designation & 313 & .731 \\
& & \\
\hline
\end{tabular}

Table shows that all three demographic variables Gender, Age and Designations are not significantly related to employees' performance in present study. Such as Gender $(F=1.276$, $\mathrm{p}>0.05)$, Age $(\mathrm{F}=.507, \mathrm{p}>0.05)$, designation $(\mathrm{F}=.313, \mathrm{p}>0.05)$.

\subsection{Regression Analysis}

Regression analysis is a statistical method used to investigate the impact of independent variable on dependent variable and also used for the purpose of predicting future value. It helps us in estimating the dependency of one variable on other where dependent variable is regressed on independent variable. 


\begin{tabular}{|c|c|c|c|}
\hline \multirow[b]{2}{*}{ Predictors" } & & \multicolumn{2}{|c|}{ Employee Performance } \\
\hline & $\beta$ & $\mathrm{R}^{2}$ & $\overline{\Delta R^{2}}$ \\
\hline \multicolumn{4}{|l|}{ Direct Effects } \\
\hline \multicolumn{4}{|l|}{ Step 1} \\
\hline Control Variables & $\cdot$ & .011 & \\
\hline \multicolumn{4}{|l|}{ Step 2} \\
\hline Organizational Justice & $.206 * *$ & & \\
\hline Organizational & & .148 & .138 \\
\hline Citizenship Behavior & $.264 * * *$ & & \\
\hline
\end{tabular}

A multiple regression was conducted to determine if Organization Justice and Organization Citizenship Behavior intake significantly predict Employees performance. The $\mathrm{H}_{1}$ and $\mathrm{H}_{2}$ states that Organization Justice and Organization Citizenship Behavior are significant predictors of Employees Performance. The results indicated that Organizational Justice and Organization Citizenship Behaviors were significant predictor of Employees performance, explaining $13.8 \%$ of the variance, $\mathrm{F}(2,187)=14.8, \mathrm{P}<0.001$. When variables were examined to evaluate their individual contribution to model, it shows that Organization Justice ( $\beta$ $\left.=.206^{* *}, p<0.01\right)$, Organization Citizenship Behavior $\left(\beta=.264^{* * *}, \mathrm{P}<0.001\right)$ made a significant contribution to the model that predicted Employees Performance.

The beta value explains that one unit increase in factor value of Organization Justice would result in .206 units (20\%) increase in Employees Performance, other variables being constant. Similarly, the beta value explains that one unit increase in factor value of Organization Citizenship Behavior would result in .264 units (26\%) increase in Employees Performance, other variables being constant. Based on these results, we can say, that the model including two variables is a significant predictor of Employees Performance.

\subsection{Summary of the Results}

Summary decision regarding three hypothesis of current study for permanent employees of public Universities of Azad Jammu and Kashmir is presented in table. 


\begin{tabular}{lc}
\hline No $\quad$ Hypothesis Statement & Results \\
\hline $\mathbf{H}_{\mathbf{1}}$ :Organization Justice has positive and significant impact & Supported \\
On Employees Performance & \\
\hline $\mathbf{H}_{2}$ :Organization Citizenship Behavior has positive and significant & Supported \\
Impact on Employees Performance & \\
\hline $\mathbf{H}_{3}$ : Organizational Justice is positively correlated with Organizational & Supported \\
Citizenship Behavior & \\
\hline
\end{tabular}

\section{Conclusion and Recommendations}

The aim of the study was to find out the effect of Organizational Justice (OJ) and Organizational Citizenship Behavior (OCB) on Employees' Performance in Universities of AJ\&K. Primary data were gathered that is adapted from previous research. In order to examine the data and hypothesis Pearson correlation and regression analysis was used. The analysis of data indicates that there is a significant relationship among Organizational Justice and Organizational Citizenship Behavior and Employees Performance. The different relationship has been made among these variables conducted by previous studies of (Colquitt, 2001; Aryee, 2002) in various cultural and work setting before.

The current study focused on the effect of OJ and OCB on Employees Performance particularly in Azad Jammu and Kashmir Universities because as in Mintzberg's typology University is a kind of professional bureaucracy that could have led to more individualistic behaviors from academicians, then in other types of organizations. It was found that Organization Justice and Organization Citizenship Behavior are positively related with each other as well as with employees' performance because according to Adam equity theory, employees work attitude and behaviors depend on the fair justice perception of organizational outcome that they received from their organization. Hence, it could be probably said that, when employees perceive fairness in the organization and belief that organization values are more concerned about each individual's well-being then they would make conscious effort to give maximum input in appropriate way. Therefore, the significant results of current study shows that employees of AJ\&K Universities have fair justice perception about their organization and they have trust on their supervisors subsequently as well as they showed extra-role behaviors in the favor of organization. Thus, it can be argued that employees behave in different ways like decreasing in deviant behavior, or a drop in absenteeism rates and enhancing work outcomes like commitment, trust and most significantly citizenship behavior which are important to make a various competitive strategy in organization.

Results of this study are consistent with the studies conducted by (Moshref-Javadi, 2006; 
Podsakoff et al., 2000; Podsakoff \& MacKenzie, 1994) suggested that the Citizenship Behavior and Organization Justice may play a substantial role in encouraging employees to stay at their current organization because Citizenship Behaviors, may improve the sense of belonging to an organization and employee determination, thus helping the organization to maintain employees and Organization Justice motivating the employees by treating them fairly at workplace within the organization.

Keeping in view the findings various recommendations are formed by researcher that could be effective for improvement and progress of employees' performance in Universities of $\mathrm{AJ} \& \mathrm{~K}$.

- Organization should promote the Citizenship Behavior at work place by providing training to employees on stress management, positive attitude and time management.

- Individual should experience constructive development programs in order to increase their motivational level which ultimately results in promoting OCB.

- Organization should build such type of environment that encourages their employees to increase performance by using managerial policies such as providing equitable rewards, respect their well-being and supportive working conditions.

\subsection{Future Research}

This research can be expanded by including more universities in study sample for more accurate and precise results with a large sample size. Furthermore this study could be carried out by using longitudinal investigation to demonstrate the casual relationship among variables reported here. This study could be conducted in other sectors like banking sector, health sector or other organization in order to generalize the results. This study could be investigated with other variables like organization structure, personality, job stress and leadership. Lastly, several demographic features (e.g. work experience) which also affect these variables were not measured here, also interrogate in future.

\section{References}

Abili, K. H., Shateri, K., Yozbashi, A., \& Faraji, D. S. H. (2009). Organizational citizenship behavior: characteristics, dimensions and outcome 1st National Conference of Management of Organizational Citizenship Behavior.

Adams, J. S. (1965) .Inequity in social exchange. In L. Berkowitz (Ed.), Advances in social psychology, 2, 267-299. New York: Academic Press. https://doi.org/10.1016/S0065-2601(08)60108-2

Adeel, M., Hashmi, U., \& Iqbal, Z. (2017). The Impact of Leadership Styles (Transformational and transactional Leadership) on Employees Job Satisfaction in the banking Sector of District kotli. The International Journal of Business and Management, 5(8), 122-129.

Alsalem, M., \& Alhaiani, A. (2007). Relationship between Organizational Justice and Employees Performance. Aledari, 108, 97-110. 
Aryee, S., Budhwar, S. P., \& Chen, X. Z. (2002). Trust as a mediator of the relationship between organizational justice and work outcomes: Test of a social exchange model. Journal of Organizational Behavior, 23, 267-285. https://doi.org/10.1002/job.138

Bateman, T. S., \& Organ, D. W. (1983). The relationship between job satisfaction and employee citizenship. Academy of Management Journal, 299-322.

Blakely, L. G., Andrews, C. M., \& Moorman, H. R. (2005). The Moderating Effect of Equity Sensitivity on the Relationship between Organizational Justice and Organizational Citizenship Behaviors. Journal of Business and Psychology, 20(2), 259-273. https://doi.org/10.1007/s10869-005-8263-3

Cohen, A., \& Vigoda, E. (2000). Do good citizen make good organizational citizens? An empirical examination of the relationship between general citizenship and organizational citizenship behavior in Israel, Administration and Society, 32(5), 596-625. https://doi.org/10.1177/00953990022019597

Colquitt, J. A. (2001). On the dimensionality of organizational justice: A construct validation of a measure. Journal of Applied Psychology, 86, 386-400. https://doi.org/10.1037/0021-9010.86.3.386

Cropanzano, R., \& Greenberg, J. (1997). Progress in organizational justice: tunneling through the maze. International Review of Industrial and Organizational Psychology, 317-372

Cropanzano, R., Bowen, E. D., \& Gilliland, W. S. (2007). The Management of Organizational Justice. Academy of Management Perspectives, 34-48. https://doi.org/10.5465/AMP.2007.27895338

Eisenberger, R., Huntington, R., Hutchison, S., \& Sowa, D. (1986). Perceived organizational

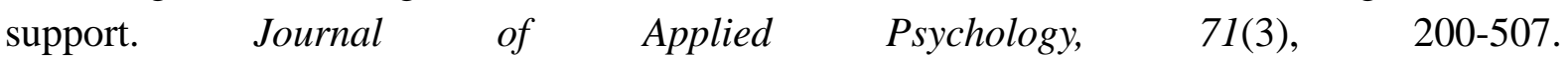
https://doi.org/10.1037/0021-9010.71.3.500

Ertürk, A. (2007). Increasing organizational citizenship behaviors of Turkish academicians: mediating role of trust in supervisor on the relationship between organizational justice and citizenship behaviors. Journal of Managerial Psychology, 22(3), 257-270. https://doi.org/10.1108/02683940710733089

Farh, J., Earley, P. C., \& Lin. S. (1997). Impetus for Action: A Cultural Analysis of Justice and Organizational Citizenship Behavior in Chinese Society, Administrative Science Quarterly, 42, 412-444. https://doi.org/10.2307/2393733

Folger, R. (1986) Rethinking equity theory: A referent cognitions model. In H. W. Bierhoff, R. L. Cohen, \& I. Greenberg (Eds.), Justice in social relations, 145-162. New York: Plenum. https://doi.org/10.1007/978-1-4684-5059-0_8

Gadot, V. E. (2007). Redrawing the boundaries of OCB? An empirical example of extra-role behavior in the workplace. Journal of Business and Psychology, 21(3), 377-405. https://doi.org/10.1007/s10869-006-9034-5 
Guangling, W. (2011). The study on relationship between employees' sense of organizational justice and organizational citizenship behavior in private enterprises. Energy Procedia, (5), 2030-2034. https://doi.org/10.1016/j.egypro.2011.03.350

Konovsky, M. A., \& Pugh, S. D. (1994). Citizenship Behavior and Social Exchange. Academy of Management Journal, 37, 656-669. https://doi.org/10.2307/256704

Leventhal, G. S. (1976a). Fairness in social relationships. In J. W. Thibaut, J. T. Spence, \& R. C. Carson (Eds.), Contemporary topics in social psychology, 211-239. Morristown, NJ: General Learning Press

Lichtenstein, D., Netemeyer, G. R., \& Maxham, G. J. (2008). The Retail Value Chain: Linking Employee Perceptions to Employee Performance, Customer Evaluations, and Store Performance. Marketing Science, 27(2), 147-167. https://doi.org/10.1287/mksc.1070.0282

Lind, E. A., \& Tyler, T. R. (1988). The Social Psychology of Procedural Justice, Plenum Press, New York, NY. https://doi.org/10.1007/978-1-4899-2115-4

Messer, A. E. B., \& White, A. F. (2006). Employees' Mood, Perceptions of Fairness, and Organizational Citizenship Behavior. Journal of Business and Psychology, 21(1), 65-82. https://doi.org/10.1007/s10869-005-9018-x

Moorman, H. M., Niehoff, B. P., \& Organ. D. W. (1993). Treating Employees Fairly and Organizational Citizenship Behavior: Sorting The Effects of Job Satisfaction, Organizational Commitment, and Procedural Justice. Employee Responsibilities and Right Journal, 6(3), 209-225. https://doi.org/10.1007/BF01419445

Moorman, R. H. (1991). The relationship between organizational justice and organizational citizenship behaviors: do fairness perceptions influence employee citizenship? Journal of Applied Psychology, 76(6), 845- 855. https://doi.org/10.1037/0021-9010.76.6.845

Moshref, J. M. H., Dalvi, M. R., \& Abdolbaghi, A. (2006). Organizational justice in the shadow of Alavi justice. Journal of Modiriyate Farda, 15-16.

Neami, A., \& Shokrkon, H. (2004). The relationship of organizational justice and organizational civic behavior of employees in Ahvaz industrial organizations. Journal of Pyschology, (12).

Organ, D. W. (1988). Organizational citizenship behavior: The good soldier syndrome. Lexington, MA: Lexington Books.

Place, W., Ballenger, J., Wasonga, T. A., Piveral, J., \& Edmonds, C. (2010). Principals' perspectives of social justice in public schools. International Journal of Educational Management, 24(6), 531-543. https://doi.org/10.1108/09513541011067692

Podsakoff, A., Mackenzie, E., Paine, C., \& Bachrach, G. (2000). Organizational citizenship behaviours: a critical review or theoretical and empirical literature and suggestions for future research. Journal of Management, 26(3), 513-563. https://doi.org/10.1177/014920630002600307 


\section{Macrothink}

International Journal of Human Resource Studies

ISSN 2162-3058 2018, Vol. 8, No. 2

Posdakoff, M. P., \& MacKenzie, B. S. (1994). Organizational Citizenship Behaviors and Sales Unit Effectiveness. Journal of Marketing Research, 31(3) (Aug., 1994), 351-363. American Marketing Management. https://doi.org/10.2307/3152222

Senobari, M. (2008). Organizational citizenship behavior: definitions, dimensions and impact facor. Journal of Tosse Ensani Police, 5(16).

Yaghobi, M., Javadi, M., Agha, R. Z. (2010). The relationship between knowledge management and students demographic characteristics in Isfahan Medical University. Iranian Journal of Education in Medical Science, Number of development and education.

Zeinabadi, H., \& Salehi, K. (2011). Role of procedural justice, trust, job satisfaction, and organizational commitment in organizational citizenship behavior (OCB) of teachers: proposing a modified social exchange model. Procedia - Social and Behavioral Sciences, 29, 1472 - 1481. https://doi.org/10.1016/j.sbspro.2011.11.387

Zinta, S. B. (2005). Fairness Reduces the Negative Effects of Organizational Politics on Turnover Intentions, Citizenship Behavior and Job Performance. Journal of Business and Psychology, 20(2), 175-200. https://doi.org/10.1007/s10869-005-8258-0

\section{Copyright Disclaimer}

Copyright for this article is retained by the author(s), with first publication rights granted to the journal.

This is an open-access article distributed under the terms and conditions of the Creative Commons Attribution license (http://creativecommons.org/licenses/by/4.0/). 